\title{
The role of serum procalcitonin and CRP levels in determining of etiology and outcome in acute exacerbations of COPD
}

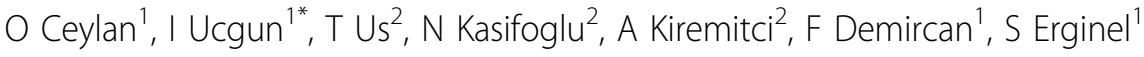 \\ From ESICM LIVES 2015 \\ Berlin, Germany. 3-7 October 2015
}

\section{Introduction}

This study was conducted to investigate the role of serum procalcitonin and CRP levels in determining etiology, treatment and prognosis in COPD patients with acute exacerbation.

\section{Methods}

Fifty-eight hospitalized COPD patients with acute exacerbation were included in the study between January 2008 and March 2011. The diagnosis of COPD was made according to the GOLD guidelines. Serum CRP and procalcitonin (PCT) levels in the first day of hospitalization and then one month later (in a stable period) were studied from all COPD patients. Patients were classified into 4 groups according to the severity of disease and divided into 2 groups according to the PCT levels $(<0.2 \mathrm{ng} / \mathrm{dl}$ and $>0.2 \mathrm{ng} / \mathrm{dl}$ ).

\section{Results}

Four (7\%) patients were female and 54 (93\%) were male. The mean age was $68.1 \pm 10.1$. Pathogenic bacterial growth was detected in 16 sputum or bronchial lavage samples. MRSA was found in 3 samples, P. aeruginosa in 3, S. maltophilia in 3, and Enterobacter species was detected in 2 samples. Chlamydia pneumoniae serology was positive in $16(29 \%)$ patients. M. pneumoniae was positive in $8(15 \%)$ patients. The rate of $\mathrm{M}$. pneumoniae was highest (40\%) in the severe exacerbation group. PCT level was significantly higher in the Chlamydia positive group ( $40 \%$ vs. $22 \%$ ). The mean CRP level of COPD patients was $6.7 \mathrm{mg} / \mathrm{l}$ in acute attack, and $2.0 \mathrm{mg} / \mathrm{l}$ in the stable period. The mean PCT level was

${ }^{1}$ Eskisehir Osmangazi University Medical Faculty, Department of Chest Dis., Eskisehir, Turkey

Full list of author information is available at the end of the article
$0.50 \mathrm{ng} / \mathrm{l}$ in acute attack, and $0.09 \mathrm{ng} / \mathrm{l}$ in the stable period. Serum PCT level was found as $0.44 \mathrm{ng} / \mathrm{l}$ in severe COPD group, and $0.2 \mathrm{ng} / \mathrm{ml}$ in the others $(\mathrm{p}=0.02) .27$ patients with acute exacerbation of COPD were diagnosed with sepsis. Six patients in the study group died. Mortality rate was higher in high PCT group (13.3\% vs. $2.5 \%$ ).

\section{Conclusions}

PCT level can help for determining acute attack and etiology in COPD patients.

\section{Authors' details}

${ }^{1}$ Eskisehir Osmangazi University Medical Faculty, Department of Chest Dis., Eskisehir, Turkey. ${ }^{2}$ Eskisehir Osmangazi University Medical Faculty,

Department of Microbiology, Eskisehir, Turkey.

Published: 1 October 2015

doi:10.1186/2197-425X-3-S1-A796

Cite this article as: Ceylan et al:: The role of serum procalcitonin and CRP levels in determining of etiology and outcome in acute exacerbations of COPD. Intensive Care Medicine Experimental 2015 3(Suppl 1):A796.

Submit your manuscript to a SpringerOpen ${ }^{\circ}$ journal and benefit from:

- Convenient online submission

- Rigorous peer review

- Immediate publication on acceptance

- Open access: articles freely available online

- High visibility within the field

Retaining the copyright to your article

Submit your next manuscript at $>$ springeropen.com

\section{SpringerOpen ${ }^{\circ}$}

C 2015 Ceylan et al.; This is an Open Access article distributed under the terms of the Creative Commons Attribution License (http:// creativecommons.org/licenses/by/4.0), which permits unrestricted use, distribution, and reproduction in any medium, provided the original work is properly cited. 